\title{
PEMBINAAN LITERASI DI PONDOK PESANTREN SABAGAI BEKAL SANTRI HIDUP BERMASYARAKAT
}

\author{
1Machsun Rifauddin \\ machsunr@gmail.com \\ 2Novi Nur Ariyanti \\ novinura932@gmail.com \\ 3 Bagas Aldi Pratama \\ bagasaldi158@gmail.com
}

1,2,3Program Studi Ilmu Perpustakaan dan Informasi Islam IAIN Tulungagung

\begin{abstract}
(Objectives) Literacy is a key element in the education system in the boarding school, but received many get negative responses in the community that the education of the trend is not in accordance with the development of the era. This research aims to explain the culture of literacy in Mbah Dul boarding school as a form of readiness of students to face life in the community later. (Method) The method used in this study is qualitative descriptive. Data is obtained through interviews, observations and documentation. Data analysis is done through data reduction process, data presentation, and draw conclusion. The validity of the data by triangulation. (Findings) The results showed that the literacy culture in Mbah Dul boarding school started from the teaching of the "kitab kuning" consisting of Badongan and Sorogan, Syawir, Muhafadzoh, Muto'laah, and Khitobah very useful for students as a provision of community life, become religious figures, Da'i, and become a pioneer of change in society. Tomorrow, the need for literacy seminars, writing training and the assignment of students to add literacy skills, strengthening media literacy
\end{abstract}

Keywords: Literacy, education system, boarding school.

\section{PENDAHULUAN}

Pendidikan merupakan salah satu kebutuhan dasar manusia diera modern saat ini. Hal tersebut benar adanya, karena pendidikan memiliki peranan yang berarti dalam arah masa depan seseorang. Selain itu, pendidikan juga mampu meningkatkan daya saing dalam dunia kerja, ilmu yang bermanfaat di masyarakat, terlebih lagi pendidikan mampu meningkatkan kualitas sumber daya manusia dari suatu negara. Sumber daya manusia yang unggul akan mempengaruhi kemajuan suatu bangsa. Indonesia yang multikultural membuat beraneka ragam suku, ras, budaya, termasuk lembaga pendidikannya. Lembaga pendidikan di Indonesia terbagi menjadi dua jenis, yakni lembaga formal seperti sekolah, dan lembaga non-formal seperti pondok pesantren. Pondok pesantren tumbuh subur di Indonesia dan menjamur ke seluruh 
penjuru nusantara. Tidak hanya itu, sistem pondok pesantren berkembang mulai dari salafiah (tradisional) dan modern. Keberadaan pnodok pesantren amatlah penting, memberikan kontribusi besar terhadap masyarakat dalam menciptakan pendidikan karakter dan khazanah keagamaan (In'amurrohman, 2019).

Berdirinya pondok pesantren di Indonesia tidak lepas dari penyebaran agama islam yang mulanya di perkenalkan oleh para wali. Pesantren merupakan lembaga pendidikan tertua yang ada di Indonesia dimana literasi menjadi modal utama para santri untuk bisa hidup bermasyarakat. Pondok pesantren tersusun dari dua unsur kata, yaitu pondok dan pesantren. Kata Pondok yang berarti kamar, rumah kecil, gubuk yang dalam bahasa Indonesia lebih menekankan sebuah kesederhanaan tempat tinggal. Pondok merupakan tempat tinggal sederhana bagi santri yang jauh dari rumah untuk menimba ilmu pada seorang kiai atau guru (Suib, 2017). Manfred Ziemek dalam Daulai (2001) menjelaskan kata pesantren berasal dari "pe-santri-an" bermakna tempat santri. Jadi, pesantren merupakan tempat tinggal para santri untuk menuntut ilmu (agama islam).

Sebagai negara berkembang, Indonesia terus berbenah dalam hal peningkatan budaya literasi sebagai pondasi pokok dalam dunia pendidikan termasuk di pendidikan podok pesantren. Merujuk pada tradisi manga di Jepang, literasi merupakan kemampuan menulis dan membaca sebagai sebuah keterampilan yang menjadi prasayarat, inti,atau dasar pembelajaran seumur hidup (Anwar dkk, 2017). Literasi yang berkembang pada pondok pesantren sangat variatif dan beraneka ragam. Literasi informasi yang berkembang di pondok pesantren lebih menekankan pada kesadaran diri. Menurut Bruce, literasi informasi adalah kemampuan mengakses, mengevaluasi, mengorganisasi, dan menggunakan informasi dalam proses belajar, pemecahan masalah, membuat keputusan formal dan informal dan konteks belajar, pekerjaan rumah, ataupun dalam pendidikan ( Septiyantono, 2016).

Salah satunya pondok pesantren berbasis salafiah di Tulungagung 
adalah Pondok Pesantren Mbah Dul, yang berada di Desa Plosokandang. Pondok Pesantren tersebut memiliki cara tersendiri dan berbeda dalam menekankan budaya literasi pada santrinya sebagai kegiatan pengasahan pengetahuan dan keterampilan. Budaya literasi yang ditekankan tidak sematamata sebagai formalitas saja, melainkan sebagai investasi masa depan seorang santri supaya siap dalam menghadapi kehidupan bermasyarakat. Masyarakat merupakan suatu kelompok yang saling berinteraksi (Tejokusumo, 2014). Kehidupan sehari-hari yang dijalani seseorang, tidak pernah lepas dari interaksi sosial dengan masyarakat. Kehidupan di masyarakat merupakan tanatangan bagi santri kedepan untuk dapak berinteraksi, berkomunikasi dan menerapkan ilmu yang telah diterima di pondok pesantren. Pendidikan literasi di pondok Pesantren menjadi sangat penting sebagai modal bagi para santri.

Permasalalahan yang terjadi adalah realitas mayoritas lulusan pesantren masih banyak yang belum mencapai kompetensi minimal pada ranah kognitif, afektif dan psikomotorik (Muhith, 2019). Masalah literasi di lingkungan pondok pesantren dimana budaya baca dan tulis yang menjadi ciri khasnya sedang mengalami kemunduran (Maskur, 2019). Penerapan konsep literasi di pondok pesantren memang sangat berbeda dengan pendidikan formal pada umumnya dan lebih terkesan unik. Sehingga banyak masyarakat yang masih meragukan kualitas pendidikan literasi di pondok pesantren dan kualitas literasi para santri. Sebagian masyarakat juga masih memiliki anggapan bahwa sistem pendidikan pesantren adalah kuno dan tidak sesuai perkembangan jaman. Namun kenyataan dilapangan berbeda, bahwa santri memiliki kemampuan baik dalam berinteraksi dengan masyarakat disamping juga ilmu pengetahuan yang dimilikinya mampu diaplikasikan di masyarakat. Disisi lain memang juga terdapat sebagian dari santri yang tidak memiliki kemampuan berinteraksi dengan baik yang disebabkan oleh kemampuan literasinya yang kurang. Berdasarkan permasalahan tersebut, 
Published by Program Studi Perpustakaan dan Ilmu Informasi FBS Universitas Negeri Padang, Indonesia

penelitian ini bertujuan untuk menjelaskan bagaimana budaya literasi bagi santri di pondok pesantren Mbah Dul dilakukan sebagai upaya untuk menghadapi tantangan kehidupan bermasyarakat dimasa mendatang.

\section{METODE}

Penelitian ini menggunakan pendekatan kualitatif, yaitu penelitian yang datanya sewajarnya atau apa adanya, tidak dirubah dengan simbol atau bilangan dengan maksud untuk menemukan kebenaran dibalik data yang obyektif dan cukup (Mundir, 2013). Pendekatan kualitatif adalah metode penelitian yang digunakan untuk meneliti obyek yang alamiah, dimana peneliti sebagai instrumen kunci (Sugiono, 2012). Dalam penelitian ini peneliti sebagai instrumen utama dalam pengambilan data yang dilakukan dengan cara wawancara, observasi dan dokumentasi. Observasi dilakukan dengan melihat kondisi lapangan secara langsung. Sedangkan wawancara terhadap saudara AF selaku lurah Pondok Pesantren Mbah Dul sebagai cara dalam mengumpulkan data di Pondok Pesantren Mbah Dul terkait literasi santri. Narasumber dipilih karena paham betul dengan kondisi literasi di Pondok Pesantren Mbah Dul dan kegunaanya kelak dimasyarakat. Terdapat dua jenis sumber data yang mendukung dalam pemecahan masalah, yakni sumber data primer dan sekunder. Sumber data primer berasal dari hasil wawancara dan observasi langsung di lapangan. Sedangkan sumber data sekunder berasal dari buku, artikel, jurnal maupun media lain yang berhubungan dengan tema pada penelitian tersebut. Analisis data menggunakan model Miles dan Huberman yaitu melalui proses reduksi data, penyajian data, dan penarikan kesimpulan. Data yang dipaparkan terkait dengan literasi dan hubungannya dengan kehidupan bermasyarakat. Hubungan yang dimaksud disini adalah pentingnya kegiatan literasi yang dilakukan santri pondok pesantren Mbah Dul terhadap kesiapan mereka dalam menghadapi kehidupan bermasyarakat kelak. Keabsahan data dilakukan dengan cara 
Published by Program Studi Perpustakaan dan Ilmu Informasi FBS Universitas Negeri Padang, Indonesia

triangulasi, yaitu membandingkan data hasil wawancara, observasi dan dokumen.

\section{HASIL DAN PEMBAHASAN}

Literasi sering dikatakan sebagai dasar dalam pendidikan sepanjang hayat seseorang. Literasi secara sederhana didefinisikan sebagai kemampuan membaca dan menulis. Kegiatan baca tulis bukan hal yang baru bagi santri di pondok pesantren, sehingga literasi juga dapat diterapkan dalam lingkup pondok pesantren sebagai modal pengetahuan. Pesantren merupakan lembaga pendidikan Islam tertua di Indonesia (Maskur, 2019), dan seiring perkembangan jaman arah pendidikan pesantren menuju ke ranah yang lebih baru.

Pada Mulanya pondok pesantren merupakan pusat pengembangan nilai dan sebagai pusat penyiaran agama Islam. Namun perkembanganya tidak hanya pada aspek spiritualitas melainkan juga melebar ke aspek politik, sosial, budaya dan pemberdayaan ekonomi masyarakat (Suib, 2017). Budaya literasi di pondok pesantren harus ditanamkan pada diri santri, agar tradisi yang dilakukan oleh ulama' terdahulu mampu untuk diteruskan oleh generasi Islam saat ini yaitu santri (Syahlan dkk, 2019). Meskipun banyak pondok pesantren modern lahir, tidak serta merta langsung menghilangkan sistem salafiyah yang cenderung sederhana dan mengutamakan pemahaman kitab kuning pada sistem pendidikannya. Kitab kuning juga masih menjadi patokan dalam berperilaku para santri dalam berbagai bidang, baik hubungannya dengan sesama santri, dengan kiai, maupun dengan masyarakat.

Pondok Pesantren salafiyah, meski dianggap sederhana, namun kaya akan makna dari sistem pendidikannya yang tidak ketinggalan jaman. Pondok Pesantren Mbah Dul mengadopsi beberapa kegiatan pembaharuan dalam mengembangkan keterampilan para santri, tetapi tidak meninggalkan tradisi sebelumnya. Tujuan akhirnya adalah agar santri dapat kembali pada masyarakat dalam keadaan siap menjadi pelopor pembangunan, baik dalam bidang agama, sosial, budaya 
Published by Program Studi Perpustakaan dan Ilmu Informasi FBS Universitas Negeri Padang, Indonesia

maupun bidang lainnya. Oleh karenanya pendidikan linterasi bagi para santri menjadi sangat penting, dimana literasi membekali mereka untuk menciptakan pengetahuan baru.

\section{Pendidikan Literasi di Pondok}

\section{Pesantren Mbah Dul}

Penerapan pendidikan literasi di pondok pesantren Mbah Dul sangat beragam. Literasi yang ditekan lebih pada penguasaan keterampilanketerampilan tertentu, dimana lebih pada mendapatkan, menyimpan dan menyampaikan informasi (Azim, 2019). Metode yang diterapkan tersebut sesuai dengan kultur pondok salafiyah pada umumnya dan pembelajatran kitab kuning menjadi ciri khas yang tidak mungkin untuk ditinggalkan. Pendidikan literasi pada pembelajaran kitab kuning mewujud pada metode pembelajaran yang digunakan, yaitu maknani, sorogan, bandongan, diskusi (syawir), dan hafalan (muhafadhoh) (Fitriyah $d k k, 2019$ ). Pada Metode yang diajarkan sudah turun-temurun sejak dahulu dan telah ditimbang dengan keperluan yang ada dimasyarakat. diantaranya sebagai berikut: a) Pembelajaran kitab kuning

1) Sorogan: Merupakan metode pembelajaran yang disimak oleh guru, sedangkan santri membaca kitab (Fitriyah dkk, 2019). Sorogan juga diartikan sebagai proses belajar mengajar yang dilakukan secara individu oleh seorang santri dengan seorang kyai (Manan dan Bajuri, 2020). Sorogan kitab kuning dimana santri membacakan kembali pelajaran yang telah diberikan dengan disimak oleh guru. Sorokan kitab kuning terbilang sangat sulit, karena santri harus menguasai ilmu nahwu dan saraf terlebih dahulu sebelum membaca kitab yang terbilang tidak ada harakatnya (AF, wawancara, 21 Maret 2020). Pelaksanaan metode sorogan di akhir pembelajaran bertujuan untuk melihat seberapa baik penyerapan santri terhadap pelajaran yang telah disampaikan guru (Fitriyah $d k k, 2019$ ). Sorogan yang ada dipondok pesantren Mbah Dul tidak hanya ada pada kitab kuning, melainkan juga Al-Qur'an pada sore dan pagi hari. Seorang santri yang membaca Al-Qur'an disimak oleh kiai dalam hal makhorijul huruf dan 
Published by Program Studi Perpustakaan dan Ilmu Informasi FBS Universitas Negeri Padang, Indonesia

tajwidnya. Jika dalam pembacaan salah maka harus diulang, atau ganti giliran selanjutnya. Seorang santri yang sorogan Al-Qur'an harus memahami ilmu tajwid sebagai dasar dalam membaca Al-Qur'an (AF, wawancara, 21 Maret 2020). melakukan sorogan tidaklah gampang, sebab perlumya kecermatan dan ketelitian dalam meminimalisir kesalahan yang mungkin timbul.

2) Badongan: merupakan metode pembelajaran kitab kuning, dimana guru membacakan kepada santri namun dalam lingkup luas (kuliah umum) kemudian santri mengisi atau memaknai kitabnya masing-masing sesuai yang dibacakan (Fitriyah $d k k$, 2019). Setelah pembacaan kitab dan maknanya, guru menjelaskan maksud dari yang telah dibakan kepada santri. Sang guru biasanya lebih mengaplikasikan pada kehidupan yang dialami santri. Secara tidak langsung, santri akan mendapatkan dasar dalam bertindak sehingga tidak terkesan ngawur. Pada sistem badongan di Pondok Pesantren Mbah Dul terbagi dalam tiga waktu, yakni malam kamis untuk kitab ta'lim muta'alim yang diikuti oleh seluruh santri. Selain hari itu ada kitab Al-adzkar untuk kelas 1 sampai 3, sedangkan kitab ihya ulumuddin untuk kelas 4 ke atas yang berlaku pada malam sabtu sampai rabu. Santri yang mengikuti kegiatan ini, harus harus teliti dan cermat, supaya dalam pemaknaan tidak salah mengartikan maksud dari apa yang ada dikitab. Hal tersebut, mencegah dari salahnya presepsi yang timbul.

3) Syawir: dapat diartikan sistem belajar bersama. Syawir berasal dari kata musyawarah yang berarti memecahkan masalah tentang suatu bab secara bersama-sama. Diskusi yang berlaku di Pondok Pesantren Mbah Dul berbeda dengan di sekolah, sebab seorang yang menyanggah permasalahan harus memiliki dasar dan sumber dari kitab kuning dan bukan bersumber dari logika semata (AF, wawancara, 21 Maret 2020). Hal ini menyiapkan seorang santri supaya menjadi pemberi solusi ditengah konflik dalam kehidupan masyarakat terkait persoalan agama kelak. 
Published by Program Studi Perpustakaan dan Ilmu Informasi FBS Universitas Negeri Padang, Indonesia

b) Muhafadzoh (hafalan): Menghafal materi pelajaran yang berwujud syair (nadhom) (Fitriyah $d k k, 2019)$. Metode ini digunakan santri dalam menghafal nadzamnya seperti kitab Al-imriti, alfiyah, tasrib, aqidatul awam, jawahirul kalamiah dan lain sebagainya. Tidak hanya itu seorang santri juga harus mau menghafal bacaan do'a, tahlil, dan seluruh amalan yang menggunakan lafadz sebagai bekal dalam mengarungi kehidupan seharihari. Metode menghafal ini terbilang sangat efektif dalam mengingat suatu bacaan dalam kurun waktu yang lama.

c) Khitobah: Merupakan salah satu metode pembelajaran mental yang ada di Pondok Pesantren Mbah Dul dalam berbicara didepan publik (pidato). Kegiatan ini biasa dilaksanakan pada malam selasa, dimana santri secara bergiliran maju ke depan menjadi pembawa acara, penceramah dan lain sebagainya. Gambaran kasarnya santri diberikan pelatihan bagaimana menjadi terlatih dalam menguasai panggung, melatih mental, dan berani berbicara dimasyarakat (AF, wawancara, 21 Maret 2020). Selain itu, kegiatan ini merupakan salah satu bentuk literasi bahasa.

d) Muto'laah: Merupakan metode belajar mandiri yang harus disadari penting oleh setiap santri. Sadar akan pentingnya hal ini, akan membuat santri rajin dalam mempelajari kitab baik dikamar maupun tempat laiinya. Santri harus mandiri dalam proses belajar, dimana mau untuk membaca dan memahami isi kitab itu (AF, wawancara, 21 Maret 2020). Hal demikian memang harus dilakukan, sesab dikelas santri kemungkinan hanya menerima 50\% dari pelajaran yang disampaikan guru. Pondok Pesantren lebih utamanya menekankan pada kesadaran diri seorang santri. Santri harus menyadari niatnya mondok untuk apa. kesadaran yang timbul akan mempengaruhi pola pikir, sikap, kebiasaan, dan gaya hidupnya selama mencari ilmu di pondok pesantren tersebut.

\section{Pentingnya Literasi Bagi Santri} Sebagai Bekal Hidup Bermasyarakat

Literasi merupakan kegiatan membaca, menulis, menganalisis, serta mengidentifikasikan informasi 
Published by Program Studi Perpustakaan dan Ilmu Informasi FBS Universitas Negeri Padang, Indonesia

(Septiyantono, 2016). Konsep literasi yang menimbulkan banyak pendapat menjadikan literasi memiliki banyak pengertian, demikian memiliki makna yang sama. Dewasa ini literasi digemborkan pada banyak bidang tanpa terkecuali masyarakat, hal tersebut guna membentuk sistem masyarakat yang literat. Masyarakat merupakan sekelompok manusia yang tinggal dalam suatu daerah dan dalam kurun waktu tertentu. masyarakat memiliki struktur masyarakat dan budaya yang terikat, hal tersebut menjadikan masyarakat lain yang tidak memahami budaya kelompok tersebut akan mengalami kesusahan untuk bergabung. Tidak jarang generasi muda terutama santri mengalami kesulitan menyesuaikan diri untuk ikut andil dalam peradaban suatu golongan masyarakat. Terlebih para santri tersebut memiliki pendidikan yang berbeda dengan umumnya masyarakat setempat.

Pondok pesantren sebagai terobosan baru dalam menyatukan dunia pendidikan dan masyarakat selalu menyesuaikan diri dengan perkembangan zaman. Hal tersebut dibuktikan dengan kegiatan pondok pesantren yang fleksibel dan pembaharuan sehingga mudah diterima oleh masyarakat. Dengan kata lain, literasi pondok pesantren merupakan investasi jangka panjang seorang santri dalam menjalani kehidupan bermasyarakat kelak yang merupakan proses pelatihan keterampilan disamping pengetahuan. Terdapat empat tingkatan literasi, yaitu performative, functional, informational, dan epistemic (Wells, 1987). Pada tingkat epstemic, orang diharapkan dapat mentransformasikan pengetahuan yang dimilikinya (Fitriyah $d k k, 2019)$, sehingga pendidikan literasi di pondok pesantren menjadi suatu kewajiban untuk membekali santri untuk terjun di masyarakat kelak. Kegiatan-kegiatan literasi yang ada di pondok pesantren Mbah Dul memiliki hubungan erat dengan kehidupan masyarakat kelak, yakni sebagai berikut:

a) Kajian kitab kuning, bertujuan dalam menjadikan santri sebagai seorang yang kelak siap dalam menghadapi 
Published by Program Studi Perpustakaan dan Ilmu Informasi FBS Universitas Negeri Padang, Indonesia

kehidupan bermasyarkat sebagai tokoh penting dalam bidang keagamaan. Kitab kuning adalah kumpulan hasil pemikiran para ulama terdahulu yang berisi pelajaran-pelajaran agama Islam (diraasah al Islamiyyah) hingga ilmu sosial dan kemasyarakatan lainnya (Fitriyah $d k k, 2019$ ). Kajian kitab dapat menjadi bekal santri untuk berdakwah agama Islam ditengah masyarakat dan menjadi garda terdepan menyebarkan ilmu pengetahuan khususnya tentang islam. Melalui kajian kitab kuning nilai lebih akan didapatkan santri, dimana ilmu agama tidak hanya bisa bermanfaat bagi diri sendiri, melainkan pada masyarakat juga (AF, wawancara, 21 Maret 2020).

b) Syawir, mampu membentuk santri menjadi seorang tokoh masyarakat yang berani dalam menyampaikan gagasan ketika sebuah persolan muncul, baik perkara tentang agama maupaun sosial (AF, wawancara, 21 Maret 2020). Pemecahan dalam masyarakat tidak lepas dari musyawarah untuk mufakat. Seorang santri akan terbiasa dalam menghadapi situasi musyawarah, sehingga tenang dan bisa berpikir sebagai pihak pemecah masalah.

c) Khitobah, merupakan sistem yang sangat pas dalam menunjang keadaan santri saat ini. Dimana ini bisa menjadi bekal dalam berbicara didepan publik, artinya tidak hanya pengetahuan saja yang ditekan melainkan keterampilan juga perlu diasah dan dikembangkan. Bahkan tidak jarang seorang santri yang telah kembali ke masyarkat akan menjadi tokoh sentral dalam berbagai acara, seperti pernikahan, khitanan, dan acara-acara lainya sebagai pemabawa acara maupun tugas lain (AF, wawancara, 21 Maret 2020).

d) Muhafadzoh, tidak hanyak akan berguna pada diri sendiri, melainkan masyarakat luas. Bagaimana tidak seorang santri pasti diperlukan dalam hal atau kegiatan yang hubungannya memimpin do'a kepada Allah SWT., seperti memakamkan jenazah, memimpin tahlilan, menjadi imam dalam sholat dan lain sebagainya $(\mathrm{AF}$, wawancara, 21 Maret 2020). Hal yang demikian tidak akan pernah lepas dari apa yang telah dihafalkannya selama hidup di pondok pesantren. 
Published by Program Studi Perpustakaan dan Ilmu Informasi FBS Universitas Negeri Padang, Indonesia

Berdasarkan penjelasan diatas, kiranya sudah tidak bisa diragukan bagaimana proses literasi yang diterapkan Pondok Pesantren Mbah Dul dalam menyiapkan santrinya supaya siap dalam kehidupan bermasyarakat kelak. Tidak hanya bidang religi yang ditekankan, melainkan juga ada sisi keterampilan literasi yang terus diasah. Transformasi literasi pondok pesantren yang progresif memang perlu disambut untuk perluasan pengetahuan santri, tetapi literasinya juga perlu dibina (Ja'far, 2019). Sebenarnya ini juga menjawab keraguan yang berkembang dimasyarakat tentang seorang yang mencari ilmu dipesantren itu bisa apa. Santri yang literat akan menjadi pembaharu, pencegah, dan agen perubahan dimasyarakat (Syahlan $d k k$, 2019).

Santri dengan modal kemampuan literasi yang baik akan mampu beradaptasi dengan kehidupan masyarakat, bahkan bisa menjadi pelopor perubahan di masyarakat melalui pengetahuan yang dimiliki dari proses literasi yang diterima. Dengan demikian mampu menjawab keraguan masyarakat bahwa kemampuan dan pengetahuan santri juga dapat berkembang seiring perkembangan jaman apabila kemampuan iterasinya terus diasah. Sealin dari bebrapa program penguatan kemampuan literasi santri perlu diberikan program tambagan seperti satu jam bersama buku, kegiatan belajar bersama yang dilakukan para santri di kamar mereka masing-masing. Kegiatan satu jam bersama buku ini sangat evektif untuk meningkatkan kemampuan literasi santri (Manan dan Bajuri, 2020). Selain itu, pendidikan literasi di pondok pesantren juga dapat dilakukan dengan seminar literasi, pelatihan menulis dan penugasan pembuatan buku santri (Syahlan $d k k$, 2019). Selain bekal literasi kitab, santri perlu juga dibekali dengan literasi media agar mampu beradaptasi dengan perubahan jaman. Ketersediaan berbagai informasi mampu memudahkan santri dalam pembelajaran, dan kesempatan memperluas wawasan (In'amurrohman, 2019).

\section{PENUTUP}

\section{Simpulan}


Literasi merupakan pokok atau pondasi suatu pendidikan, termasuk pondok pesantren. Santri yang belajar di pondok pesantren Mbah Dul diajarkan literasi dengan sistem yang unik supaya bisa mempersiapkan diri dalam kehidupan masyarakat kelak, seperti khitobah, kajian kitab kuning, syawir, muhafadzoh, dan mutola'ah. Kehidupan bermasyarakat disini menjadi penting untuk digaris bawahi, sebab santri akan menjadi tumpuan dan menjadi tokoh pembangunan yang senantiasa berguna dan digunakan dalam kehidupan sosial. Hal itu dapat tercermin ketika seorang santri memimpin kegiatan keagamaan, menjadi pembawa acara suatu kegiatan, bahkan tidak jarang berhubungan dengan hal-hal lain. seolah hal tersebut menjawab keraguan yang ada dimasyrakat, bahwa seorang santri yang mondok bisa segalanya.

\section{Saran}

Pelaksanaan kegiatan literasi di pondok pesantren Mbah Dul perlu ditingkatkan, agar kualitas lulusan sesuai dengan peran yang ada dimasyarakat. Selain itu, seorang santri perlu menyadari tentang penyampaian ilmu saja tidak cukup, ia harus rajin dan mandiri dalam mempelajari dan mengulas pelajaran yang telah diberikan. Daris situ dapat ditarik kesimpulan bahwa pondok pesantren merupakan tempat yang sesuai dalam pembentukan karakter seseorang melalui kegiatan literasinya supaya bermanfaat dimasyarakat kelak.

\section{DAFTAR PUSTAKA}

AF. (2019). "Literasi Santri Pondok Pesantren". Hasil Wawancara: 21 Maret, Pondok pesantren Mbah Dul, Tulungagung.

Anwar, R. K., Komariah, N., \& Rahman, M. T. (2017). Pengembangan Konsep Literasi Informasi Santri: Kajian Di Pesantren Arafah Cililin Bandung Barat. Wawasan: Jurnal Ilmiah Agama Dan Sosial Budaya, 2 (1), 131142.

https://doi.org/10.15575/jw.v2 i1.964

Azim, A. A. (2019). Tradisi Literasi Pesantren (Manajemen Pendidikan Literasi Di Pesantren 
Published by Program Studi Perpustakaan dan IImu Informasi FBS Universitas Negeri Padang, Indonesia

Kreatif Baitul Kilmah

Yogyakarta). TESIS. Pascasarjana

UIN Sunan Kalijaga Yogyakarta.

Daulai, H. P. (2001). Historisitas dan

Eksistensi Pesantren dan

Madrasah. Yogyakarta: Tiara

Wacana.

Fitriyah, L., Marlina, \& Suryani. (2019).

Pendidikan Literasi pada

Pembelajaran Kitab Kuning di

Pondok Pesantren Nurul Huda

Sukaraja. Titian Ilmu: Jurnal

Ilmiah Multi Sciences, 11 (1), 20-

30.

https://doi.org/10.30599/jti.v1

$1 \mathrm{i} 1.351$

In'amurrohman, F. (2019).

Kesyubhatan TIK: Sisi Gelap Dan

Terang Penggunaan TIK Pada

Literasi Digital Pondok

Pesantren. Medika Teknika :

Jurnal Teknik Elektromedik

Indonesia, 1 (1), 25-29. DOI:

10.18196/mt.010105

Manan, M. A., Bajuri, M. (2019). Budaya

Literasi di Pesantren Salafiyah

Syafi'iyah Sukorejo. Jurnal

Pendidikan Islam Indonesia, 4

(2), 116-123. DOI 10.35316/jpii.v4i2.194

Maskur, A. (2019). Penguatan Budaya

Literasi di Pesantren. IQ (IImu

Al-qur'an): Jurnal Pendidikan

Islam, 2 (1), 1-16.

Muhith, A. (2019). Pembelajaran

Literasi Membaca di Pondok

Pesantren Sidogiri Kraton

Pasuruan. Journal of Islamic

Education Research, 1 (1), 34-50.

Muhith, A. (2019). Pembelajaran

Literasi Membaca di Pondok

Pesantren Sidogiri Kraton

Pasuruan. Journal of Islamic

Education Research, 1 (1), 34-50.

Mundir. (2013). Metode Penelitian Kualitatif dan Kuantitatif. Jember: Stain Jember Press.

Soekanto, S., \& Sulistyowati, B. (2015). Sosiologi Suatu Pengantar. Jakarta: Rajawali Pers.

Sugiono. (2012). Memahami Penelitian Kualitatif. Bandung: CV Alfabeta.

Suib, M. S. (2017). Sinergitas Peran Pondok Pesantren Dalam Peningkatkan Indek Pembangunan Manusia ( IPM ) Di Indonesia. Jurnal Islam Nusantara, 1 (2), 171-191. 


\section{Info Bibliotheca}

Jurnal Perpustakaan dan IImu Informasi

ISSN 2714-805X

Page : 99-112

Published by Program Studi Perpustakaan dan Ilmu Informasi FBS Universitas Negeri Padang, Indonesia

Syahlan, T., Imran, A., Zulfa, L. N., \& Ma,

as S. (2019). Pendampingan

Santri untuk Membangun

Tradisi Literasi Di Pondok

Pesantren Al-Mubarok

Mranggen Demak. Dimas, 19 (1),

49-60.

Tejokusumo, B. (2014). Dinamika masyarakat sebagai sumber belajar ilmu pengetahuan sosial. Geoedukasi, 3, 38-43.

Septiyantono, T. (2016). Literasi Informasi. Jakarta: Universitas Terbuka.

Wells, G. (1987). Apprenticeship in literacy. Interchange, 18(1-2), 109-123.

https://doi.org/10.1007/BF018

07064 